\title{
Estimating soil erosion in sub-Saharan Africa based on landscape similarity mapping and using the revised universal soil loss equation (RUSLE)
}

\author{
Lulseged Tamene $\cdot$ Quang Bao Le
}

Received: 15 April 2014 / Accepted: 13 January 2015/Published online: 22 January 2015

(C) Springer Science+Business Media Dordrecht 2015

\begin{abstract}
Soil erosion is one of the major forms of land degradation in sub-Saharan Africa (SSA) with serious impact on agricultural productivity. Due to the absence of reliable data at appropriate resolution and differences in the methods used, there are discrepancies in soil erosion estimates at both continental and basin levels. This study attempts to contribute to the existing regional soil erosion estimates based on a two-stage approach. First, we partitioned SSA into environmental units, so-called similar environmental constraint envelops (SECEs), using broad scale data as
\end{abstract}

Electronic supplementary material The online version of this article (doi:10.1007/s10705-015-9674-9) contains supplementary material, which is available to authorized users.

\section{Tamene $(\bowtie)$}

International Center for Tropical Agriculture (CIAT), Chitedze Agricultural Research Station,

P.O. Box 158, Lilongwe, Malawi

e-mail: Lt.desta@cgiar.org

Q. B. Le (ه)

Department of Environmental Systems Science, Swiss Federal Institute of Technology Zurich (ETH Zurich), Universitaestrasse 22, 8092 Zurich, Switzerland

e-mail: quang.le@env.ethz.ch

Q. B. Le

CGIAR Research Program on Dryland Systems, C/o International Center for Agricultural Research in Dry Areas (ICARDA), 15 Khalid Abu Dalbouh St., Abdoun Eshamali, Amman 11195, Jordan

e-mail: q.le@cgiar.org proxies of erosion drivers. The SECEs are intended to provide spatial frame for scaling out modeled erosion results. Second, soil erosion estimate is made at two selected basins of the White Volta and the Nile using spatially distributed revised universal soil loss (RUSLE) model. The delineation of SECEs across SSA provided spatially differentiated clusters governed by the existence of similar environmental conditions and soil erosion risk levels. The RUSLE-based estimates show that soil erosion ranges between 0 to $120 \mathrm{t}$ $\mathrm{ha}^{-1} \mathrm{yr}^{-1}$ (overall mean of $35 \mathrm{t} \mathrm{ha}^{-1} \mathrm{yr}^{-1}$ ) in the White Volta basin, and $0-650 \mathrm{t} \mathrm{ha}^{-1} \mathrm{yr}^{-1}$ (overall mean of $75 \mathrm{tha}^{-1} \mathrm{yr}^{-1}$ ) in the Nile basin. The soil loss estimates show an overall agreement with other studies conducted in the two basins. Our approach provides guidance on where empirically estimated soil erosion for a given SECE can be extrapolated to similar SECE's with acceptable confidence and where finer SECE's sub-units should be defined to further collapse the spatial variability of drivers of erosion.

Keywords Soil erosion - Erosion modeling · Landscape similarity · RUSLE - White Volta Basin . Nile Basin · Sub-Saharan Africa

\section{Introduction}

Due to population pressure, land degradation, low input use and climate change, the majority of farming communities in sub-Saharan Africa (SSA) are locked 
in poverty and food insecurity with earnings below the poverty line of 1.5 USD per day (Vlek et al. 2010, Hazell et al. 2010). With limited resources to invest in land management, the continued pressure on resources further aggravate land degradation due to soil erosion, soil nutrient mining, deforestation and biodiversity loss. Though consistent studies covering wide geographical areas are limited, some studies show that about 490 million ha land in Africa (about $16 \%$ of the total area) are affected by different types of degradation (FAO 1995; Batjes 2001). It is also estimated that $65 \%$ of SSA's agricultural land is degraded because of water and soil erosion, chemical and physical degradation (Oldeman et al. 1991; Scherr 1999). Due to the severity of land degradation coupled with climate change and rainfall variability, agricultural productivity in SSA stagnates and remains low as evidenced in hunger and poverty levels in the region despite overall global advances in biotechnology (Ejeta 2010; Abe and Wakatsuki 2011).

Soil erosion is generally considered the most severe threat to land productivity creating negative impacts on agricultural production, infrastructure and water quality (Vrieling 2006; Obalum et al. 2012). Lal (1995) estimated that past erosion in Africa has caused yield reduction of 2-40\%, and that if present trend continues, the yield reduction by 2020 may be $16.5 \%$. Due to extensive soil erosion, poor management, or insufficient use of inputs, soil nutrient depletion is another major land degradation problem in SSA (Bishop and Allen 1989; Stocking 1987; Sanchez et al. 1997). During the 2002-2004 cropping season, about $85 \%$ of African farmland had nutrient mining rates of more than $30 \mathrm{~kg} \mathrm{ha}^{-1} \mathrm{yr}^{-1}$ and $40 \%$ had rates $>60 \mathrm{~kg} \mathrm{ha}^{-1} \mathrm{yr}^{-1}$ (Henao and Baanante 2006).

In spite of the fact that the problem of land degradation is particularly severe in SSA, little consistent and reliable data are available both on its extent and its impact on productivity (FAO 1995; Lal 1995; Stocking and Benites 1996; Eswaran et al. 2001; Warren et al. 2001; Obalum et al. 2012). As a result, there is still a debate whether the problem of land degradation really reached levels, which seriously threaten the land, the economic future of the continent and the livelihoods of its inhabitants (Symeonakis and Drake 2010). This impairs the preparedness and willingness of international organizations, policy and decision makers to invest in measures that can help tackle land degradation. The absence of accurate and detailed benchmark about the current status of land resources also restricts the ability to monitor change over time. There is therefore a need for improved understanding of erosion processes and their interactions as well as identify hotspot areas of concern in order to guide conservation planning. Currently, the availability of remote sensing data, advancements in computation and data integration in a geographic information system (GIS) have enhanced the possibility to map and identify hotspots areas where conservation priority is needed.

The aim of this study is to provide a two-stage approach to better estimate soil erosion risk for the SSA sub-continent. First 'similar environmental constraint envelops (SECEs)' are developed by integrating broad scale data (e.g., climate, terrain, soil, and land cover) as proxies of soil erosion drivers. The principle behind SECEs is that different areas having the same SECE type should have their soil erosion rate within the same severity class. With this, empirically estimated soil erosion for a given SECE can be extrapolated to similar SECEs with defined uncertainty. Next, quantitative soil loss is estimated using the revised universal soil loss equation (RUSLE) in two example basins of the White Volta and the Nile. The RUSLE is selected over other models considering ease of use, data availability and wide applicability. The net soil loss (NSL) is then computed for the different SECE clusters and the level of uncertainty calculated. This calculation provides guidance on where the estimated NSL can be extrapolated with an acceptable confidence and where finer SECE sub-units should be defined to collapse the spatial variability of drivers of erosion. The results of the study can be of preliminary use in land use planning and management efforts as well as serve as a benchmark against which future trends can be compared.

\section{Methodology and data sources}

Study area

Broadly, this study is conducted across SSA where easily available data were used to derive similar environmental constraint envelopes (SECEs). For detailed assessment, two basins (the White Volta and the Nile) were exemplarily analyzed using the RUSLE adjusted for sediment delivery ratio (SDR). 


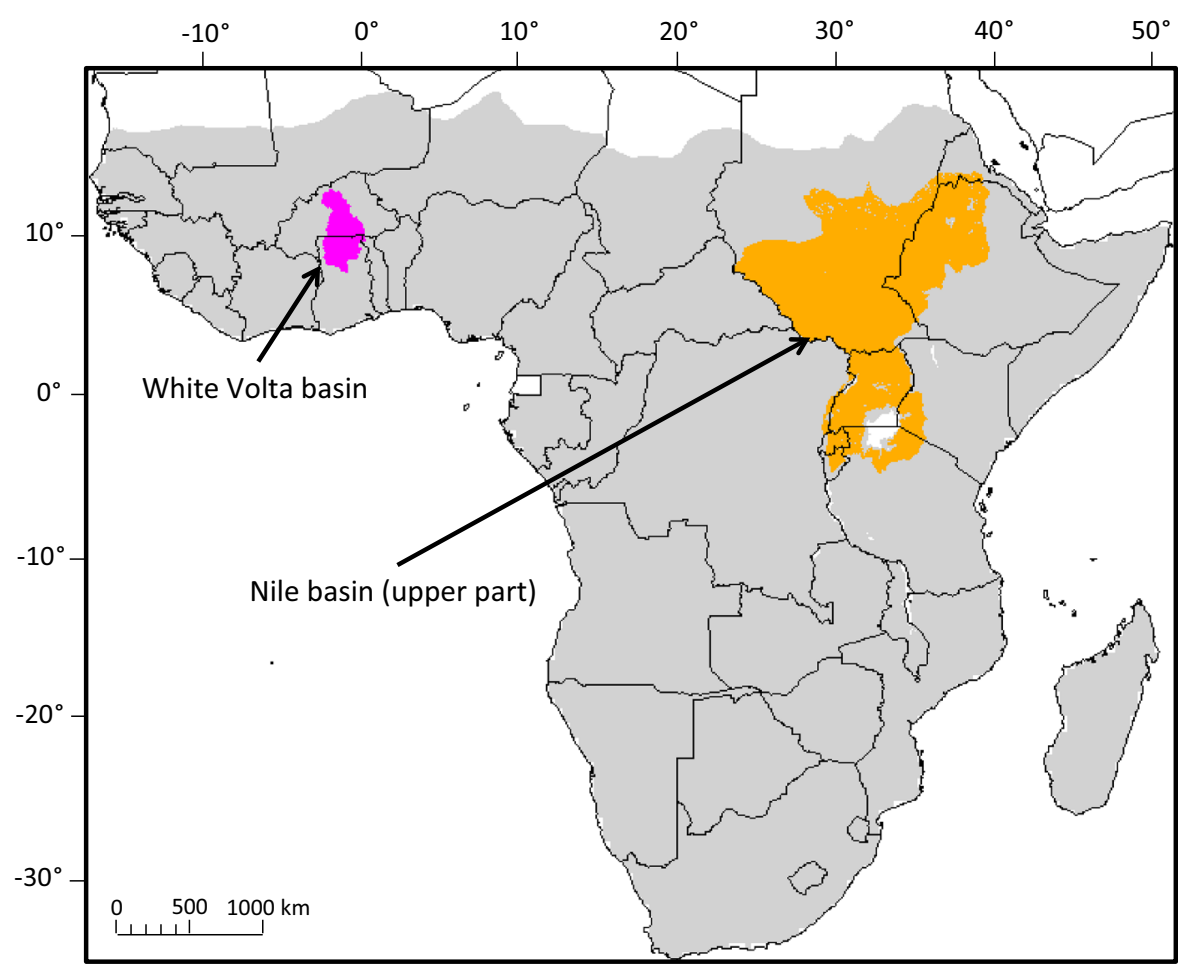

Fig. 1 Sub-Saharan Africa (in grey) and the locations of the White Volta and the Nile (upper) basins. (Color figure onlie)

The White Volta is a sub-river basin of the Volta basin, covering an area of $106,000 \mathrm{~km}^{2}$, predominantly in Ghana and Burkina Faso (Fig. 1). The subbasin is situated within the semi-arid West African savanna zone, and accommodates about 7 million people with 61 people $\mathrm{km}^{-2}$ (Balk and Yetman 2004). The basin is known to suffer from severe degradation. Between 1965 and 1995 the natural vegetation declined from 43 to $13 \%$ of the total basin area in Burkina Faso with a concomitant increase in cultivated areas from 53 to $76 \%$ while bare soil increased from 4 to $11 \%$ (Droogers et al. 2006).

The Nile Basin, shared by about eleven counties in the eastern and central Africa region (Fig. 1), covers an area of 2.9 million $\mathrm{km}^{2}$ (about $10 \%$ of the African continent). With a course of $6,695 \mathrm{~km}$, the Nile is the longest river in the world and its drainage basin represents the longest route of sediment transport. It is mainly formed by the White and Blue Nile basins. Lake Victoria, the second largest freshwater body in the world with a surface area of $68,500 \mathrm{~km}^{2}$, is the source of the White Nile (Fig. 1), which has a catchment area of $184,000 \mathrm{~km}^{2}$. On the other hand, the Blue Nile is originated from Lake Tana in the
North Western part of Ethiopia. The upper Blue Nile basin has an area of $184,560 \mathrm{~km}^{2}$ and is fed by many tributaries especially inside Ethiopia. The Blue Nile carries large amount of water and soil towards the Sudan and Egypt. The Blue Nile and the White Nile join in Khartoum to form the Nile River that flows northeast and continues its course up to Egypt where it enters Lake Nasser and flows further downstream to enter the Nile Delta before reaching the Mediterranean Sea (Fig. 1). The Nile basin accommodates about 238 million people and has diverse land use/cover types (Nile Basin Initiative 2012).

\section{Developing similar environmental constraint} envelops (SECEs)

The fundamental of SECEs is based on the principle that landscape features and the corresponding processes are results of amalgamation of different natural forces. Similar environmental units or situations can prevail when similar natural processes take place or when similar forces of human action are exerted. With this background, it could be possible to 'cluster' similar environmental units by systematically integrating 
relevant natural and human processes (Bull et al. 2003; Hochschild et al. 2003). Development of SECEs possibly dictated by the co-existence of similar biophysical and human-induced (e.g., land uses) drivers can help understand the principal governing forces and thus devise suitable management or adaptation mechanisms.

In this study, broad classes of biophysical driving forces of soil erosion-including climate (mean annual rainfall), terrain (slope), soils (texture) and land cover types, derived from different sources (Table 1) were systematically integrated in a GIS platform to derive SECEs across SSA. Since the SECEs are derived based on attributes that control erosion processes, they can represent potential areas of similar erosion problems and serve as proxies to erosion potential maps. The SECEs not only designate areas of similar environmental conditions but also can be used to complement modeling results. The procedure followed to derive SECEs is illustrated in Table 1. Spatial data processing and analysis were conducted in an Arc GIS 10.0 platform. All the data were adjusted to a spatial resolution of $1-\mathrm{km}$ cell size.

\section{Parameterization of the RUSLE model}

The kind of model applied generally depends on the purpose at hand but also the availability and quality of data related to the area under consideration. For areas where quality data for model building and calibration are scarce, empirical models such as the RUSLE may give better approximation of soil loss (Renard et al. 1997) compared to complex physical based models that require detailed data (Garg and Jothiprakash 2012; Chowdary et al. 2013). Accordingly, the RUSLE adjusted for SDR is used in this study to assess soil erosion risk with a spatial resolution of $250 \mathrm{~m}$ at regional scale. RUSLE is formulated as (Renard et al. 1997):

$\operatorname{RUSLE}\left(\mathrm{t} \mathrm{ha}^{-1} \mathrm{y}^{-1}\right)=R \times K \times L S \times C \times P$

where $R$ is rainfall erosivity (MJ mm ha ${ }^{-1} \mathrm{~h}^{-1} \mathrm{y}^{-1}$ ); $K$ is soil erodibility (t ha h (ha $\mathrm{MJ} \mathrm{mm})^{-1}$ ); $L S, C$ and $P$ are the coefficients (-) of the slope length-steepness, land use/cover, and conservation/management factors, respectively.

In this study, the Stream Transport Capacity Index (STCI) is used to calculate the $L S$-factor (Moore and Burch 1986; Moore et al. 1991):

$L S=(m+1)\left[\frac{A_{s}}{22.13}\right]^{m}\left[\frac{\sin \beta}{0.0896}\right]^{n}$

where $m$ and $n$ are slope length and angle coefficients, respectively; $A_{s}$ is the specific upslope contributing area per unit length of contour; $\beta$ is the local slope gradient (degree).

The $L S$ calculation was made after processing the ASTER-derived $90 \mathrm{~m}$ resolution digital elevation model (DEM). The resulting $L S$ factor was then resampled to a resolution of $250 \mathrm{~m}$ in order to make the slope and upslope area calculations consistent with other datasets used in the modelling exercise.

Table 1 Definition of similar environmental constraint envelops (SECEs) relevant to soil erosion risk assessment and related data sources

Main components of SECE

\begin{tabular}{llll}
\hline Classes of mean annual rainfall $(\mathrm{A})^{1}$ & Classes of surface slope $(\mathrm{B})^{3}$ & Class of topsoil texture $(\mathrm{D})^{4}$ & Class of land cover $(\mathrm{E})^{6}$ \\
$1=$ Arid $(<500 \mathrm{~mm} / \mathrm{yr})$ & $1=$ Flat $\left(<5^{\circ}\right)$ & $1=$ Fine & $1=$ Forested land \\
$2=$ Semiarid $(500-800 \mathrm{~mm} / \mathrm{yr})$ & $2=$ Relatively flat $\left(5^{\circ}-10^{\circ}\right)$ & $2=$ Medium & $2=$ Mosaic forest-shrub/grass \\
$3=$ Subhumid $(800-1,300 \mathrm{~mm} / \mathrm{yr})$ & $3=$ Gentle slope $\left(10^{\circ}-15^{\circ}\right)$ & $3=$ Coarse & $3=$ Shrub land \\
$4=$ Humid $(>1,300 \mathrm{~mm} / \mathrm{yr})$ & $4=$ Steep $\left(15^{\circ}-25^{\circ}\right)$ & $5=$ Cropland \\
& $5=$ Very steep $\left(>25^{\circ}\right)$ & $6=$ Sparse vegetation or bare soil
\end{tabular}

Data source:

Data source: GAEZ $2008^{5} \quad$ Data source: GAEZ $2008^{5}$

Data source: Globcover 2005-2006

CRU TS $3.1^{2}$

The digital code of an SECE has four strictly ordered digits: ABDE. For example, an SECE unit coded "3415" indicates the combination of Sub-humid climate, Steep slope, Fine soil texture and Cropland classes

1 Vlek et al. (2010); ${ }^{2}$ (Jones and Harris 2008); ${ }^{3}$ Tamene et al. (2014); ${ }^{4}$ modified from Fischer et al. (2008); ${ }^{5}$ Fischer et al. (2008);

${ }^{6}$ adapted from Vlek et al. (2010); ${ }^{7}$ Bicheron et al. (2008) 
The $R$-factor is defined as the product of kinetic energy and the maximum 30-min intensity and shows the erosivity of rainfall events (Wischmeier and Smith 1978; Renard et al. 1997). In situations where rainfall intensity data with adequate spatial coverage is not available, the relationship established between mean or monthly rainfall and rainfall intensity can be used to estimate $R$-factor (Renard and Freimund 1994; van der Knijff et al. 2000; Yang et al. 2003; Lawal et al. 2007; Le Roux et al. 2008; Xin et al. 2010). In this study, we applied the models developed by Roose (1977) and Hurni (1985) for the White Volta and the Nile basins, respectively. The two models are given as:

$R_{R}=0.557 \times M A P-5.766$

$R_{H}=0.360 \times M A P+47.6$

where $\mathrm{R}_{\mathrm{R}}$ and $R_{H}$ are rainfall erosivities based on Roose (1977) and Hurni (1985), respectively; MAP $=$ mean annual precipitation $(\mathrm{mm})$.

For the Volta basin, rainfall data available for 200 stations in northern Ghana and Burkina Faso were used to derive erosivity while for the Nile basin it was based on Climatic Research Unit (CRU) time series rainfall data (Jones and Harris 2008). Both datasets were resampled to a cell size of $250 \mathrm{~m}$ in order to make them consistent with the other datasets used to estimate soil loss.

Soil erodibility ( $K$-factor) is the inherent property of a soil that plays major role in the ability of water to detach and transport its particles. Some of the major soil properties that affect soil erosion and based on which erodibility is estimated include soil texture, soil organic matter, soil structure and basic permeability of the soil profile (Wischmeier et al. 1971; Renard et al. 1997). Since information on texture, organic matter, structure and permeability especially at large geographical coverage are scarce, various studies attempted to estimate $K$-factor based on soil types (Veldkamp 2002; Roy et al. 2003; FAO 2004; Symeonakis and Drake 2004, 2010).

For the Volta basin, the $K$-factor was derived from the FAO-IIASA soil map (Fischer et al. 2002) and the translation of soil types into $K$-factor values (ton ha ${ }^{-1}$ $\mathrm{yr}^{-1}$ ) was based on Folly (1997). For the Nile basin, $K$ factor values were derived based on:

$K=\frac{\left\lceil 2.1 M^{1.14}\left(10^{-4}\right)(12-O M)\right\rceil}{7.59}$ where, $K=$ soil erodibility, $O M=$ soil organic content $(\%), M=((\%$ silt $+\%$ sand $) \times 100-\%$ clay $)$. Soil organic content, silt, sand, and clay percentages of the top soil layer $(0-20 \mathrm{~cm})$ were derived from ISRIC Africa dataset (ISRIC 2013). Generally Eq. 5 can help capture relative differences in erodibility between soil types and help approximate the resistance to erosion of different soils under consideration.

The $C$-factor is defined as the ratio of soil loss from land with specific crop or vegetation to the corresponding soil loss from tilled and bare soil (Wischmeier and Smith 1978). It is intended to capture differences in soil loss due to variability in surface cover since areas of dense vegetation have high total roughness, which increases infiltration and reduces runoff, and vice versa (Desmet and Govers 1996; Bull et al. 2003).

Since $C$-factor values for the RUSLE are calibrated for conditions in the United States, attempts have been made to develop local and/or regional $C$-factor values by different researchers. Satellite derived vegetation indices have been found to be good proxy for land cover on relatively large basins and were applied in various regions (van der Knijff et al. 1999, 2000; Van Leeuwen and Sammons 2003, 2005; Van Rompaey et al. 2005). In this study, the MODIS Normalized Difference Vegetation Index data (annual mean over the period 2001-2008) with a spatial resolution of $250 \mathrm{~m}$ have been used to estimate the $C$-factor and account for the effect of differences in vegetation surface cover on soil loss (van der Knijff et al. 1999, 2000; Van Leeuwen and Sammons 2005):

$C=\exp \left[-\alpha \times \frac{N D V I}{(1-N D V I)}\right]$

where $C$ is $C$-factor that determines the frictional resistance of land surface to runoff and erosion; $\alpha$ is a unit-less parameter that determines the shape of the curve-relating NDVI and the $C$-factor (van der Knijff et al. 1999, 2000). In relation to MODIS data, $\alpha$-value of 2.5 which gives reasonable results (Van Leeuwen and Sammons 2003, 2005) was used in this study.

$P$-factor gives the ratio between the soil loss expected for a certain soil conservation practice to that with up-and down-slope plowing (Wischmeier and Smith 1978). As values for $P$-factor are not available for the region and since it was not possible to derive appropriate values from similar regions, we 
used a $P$-factor value of 1 for this study. This assumes that no significant conservation measures are in place to counter soil loss and sediment yield at the basin scale. This may not have an overestimation effect as well-maintained conservation structures in the basins are rare (Mati and Veihe 2001) except for localized interventions (e.g., Kaboré and Reij 2004; Reij et al. 2005) whose basin level impacts may not be very significant.

Evaluation of RUSLE model results and uncertainty of SECE-based erosion assessment

In regional modelling exercises like this study the main target is to assess 'erosion risk and map spatial variability' and not to provide detailed quantitative measurement of magnitude of soil erosion. We thus believe that accuracy required for assessing spatial variability of soil loss is not expected to be as rigorous as those intended for modeling method-inspired studies. As a result, our model evaluation is mainly focused on comparing our model results with results of other studies in the same environment. We compared the soil loss risk estimates for the two basins with results of other studies within the respective study sites. Data- and parameterization-induced uncertainties of the RUSLE results were also discussed.

The main purpose of the present study is to estimate soil loss risk over large geographical region based on the aggregation of pixel-based RUSLE results for spatial SECE clusters. There will be associated uncertainties when extracting soil loss estimates for each SECE cluster. To measure statistical uncertainties of the SECE-averaged NSL (that is proposed to be used to extrapolate to similar SECEs in the region), we use confidence interval of the mean at a reliability of $95 \%\left(C I_{0.05}, p<0.05\right)$ (Curran-Everett and Benos 2004):

$\mathrm{CI}_{0.05}=\mathrm{t}_{\mathrm{df}, \alpha / 2} \times \frac{\mathrm{SD}}{\sqrt{\mathrm{n}-1}}$

where $t_{d f, \alpha / 2}$ is the value from t-table at $d f=n-1$ ( $n=$ number of spatial clusters within the SECE) and $\alpha / 2=0.05 / 2=0.025$ (2-tails), $S D$ is the standard deviation of the SECE-averaged NSL. In addition, the percentage of $C_{0.05}$ compared to the averaged NSL was calculated.

\section{Results and discussion}

Similar environmental constraint envelops (SECEs)

The combination of mean annual rainfall (4 classes), surface slope (5 classes), topsoil texture (3 classes) and main land cover types (6 classes) resulted in 190 units of SECE. The areas of these units are shown in Table S1 (Supplementary Information). The SECEs form 'cluster' of landscape units with similar potentials, constraints and processes systematically grouped based on common attributes. In order to make the SECEs manageable and especially show spatial variability with understandable legend, SECE units with total area over SSA $<10 \mathrm{~km}^{2}$ and areas with few pixels $(<10$ pixels) were excluded. Figure 2 shows the spatial pattern of the 19 main SECEs across SSA.

The basis of the SECEs is that different erosion process dynamics are linked to certain associations of system component properties (Flügel 1996, 1997; Flügel et al. 2003; Marker et al. 2001). As a result, entities with the same erosion process dynamics consist of certain associations of system characteristics and system inputs whereby a drainage system can be perceived as an assembly of spatial process entities with different potentials (Hochschild et al. 2003). Other studies such as Fargas et al. (1997) developed a method to identify sites of sediment emission risk through qualitative ratings of basic terrain data. Bull et al. (2003) developed the concept of hydrologically similar surfaces, distributed homogeneous units within a catchment based on key runoff producing variables of land use, slope and geology, resulting in similar runoff response. As the SECEs are explicitly defined by major biophysical drivers of soil and water redistribution over the land surface, they can be used to designate landscape positions with similar constraint types and levels. The SECE map can also provide guidance towards the development of suitable land degradation indicators as well as a basis where detailed land degradation and other environmental studies should focus. In the next steps of this study, the SECEs were used as spatial basis to aggregate NSL based on pixel-based RUSLE soil erosion assessment in selected basins. 


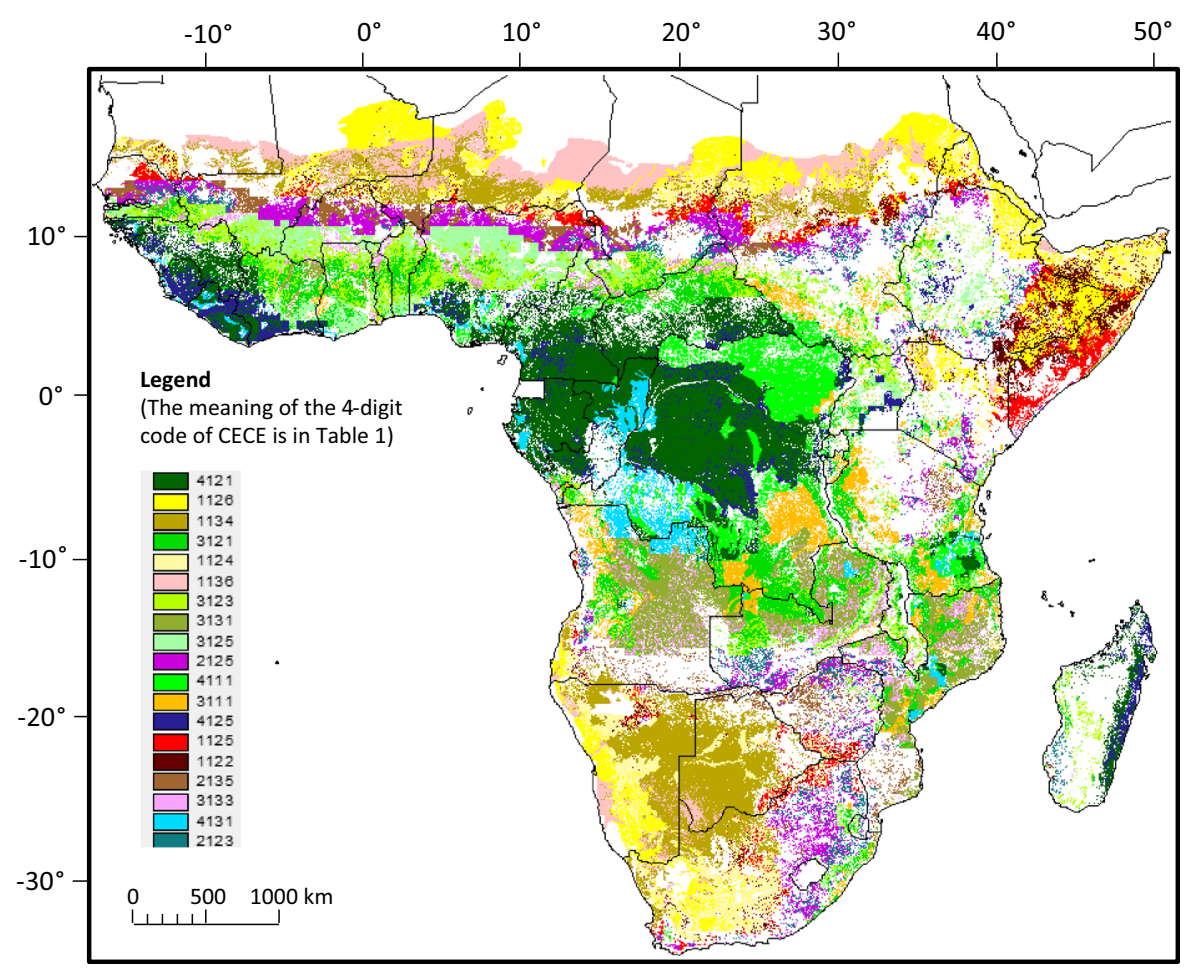

Fig. 2 The SECEs over sub-Saharan Africa (SSA). Notes on map legend: pixel size $=1 \mathrm{~km}$, pixel value = SECE's digital code with the format defined in Table S1; the number of SECEs $=320$. (Color figure online)

Soil loss rate and its spatial distribution

\section{Soil loss estimate and its spatial pattern in the White Volta basin}

The average gross soil erosion estimated for the White Volta basin using the RUSLE model was about $75 \mathrm{t}$ $\mathrm{ha}^{-1} \mathrm{yr}^{-1}$. When corrected for SDR, the mean NSL reduced to about $35 \mathrm{t} \mathrm{ha}^{-1} \mathrm{yr}^{-1}$. Thus, about $50 \%$ of the soil eroded upslope is deposited within the subbasin. However, it has to be noted that few areas show very high soil loss that increased the overall mean. When we exclude these high soil loss areas mostly at steep slopes representing $<1 \%$ of the area, the overall soil loss reduced to $27 \mathrm{t} \mathrm{ha}^{-1} \mathrm{yr}^{-1}$. In addition, over $75 \%$ of the area experienced soil loss below $8 \mathrm{t}$ $\mathrm{ha}^{-1} \mathrm{yr}^{-1}$ indicating how the few extreme high soil losses exaggerated the overall soil erosion estimate based on the RUSLE.

In term of the spatial pattern of NSL, the northeastern part of the White Volta sub-basin lost over $15 \mathrm{t}$ $\mathrm{ha}^{-1} \mathrm{yr}^{-1}$ whereas for the central and western parts it was $<5 \mathrm{t} \mathrm{ha}^{-1} \mathrm{yr}^{-1}$ (Fig. 3). Similarly, the Upper East region of Ghana and most places bordering GhanaBurkina Faso showed sediment yield more than $15 \mathrm{t}$ $\mathrm{ha}^{-1} \mathrm{yr}^{-1}$, whereas the southern parts of the basin showed sediment yield of $<5 \mathrm{tha}^{-1} \mathrm{yr}^{-1}$. Based on this, the specific places where soil loss is comparatively high and thus immediate management measures are needed included the Upper East Region of Ghana and the northeastern parts of the sub-basin in Burkina Faso (Fig. 3).

The purpose of the pixel-based soil erosion assessment is to provide spatial basis for gauging average NSL of SECE (i.e., SECE-averaged NSL) that can be extrapolated to landscape units of similar SECE. It is thus essential to evaluate the model results. Since no similar basin scale results of other studies are available, we compared our NSL results for several subcatchments against findings of other studies that were based on field measurement or used the same model but with different data sources. Table 2 shows that the sub-catchment average NSL values measured in the different studies agree fairly well with the NSL predicted in this study. The agreements reported in Table 2 and those of other studies thus lend confidence 


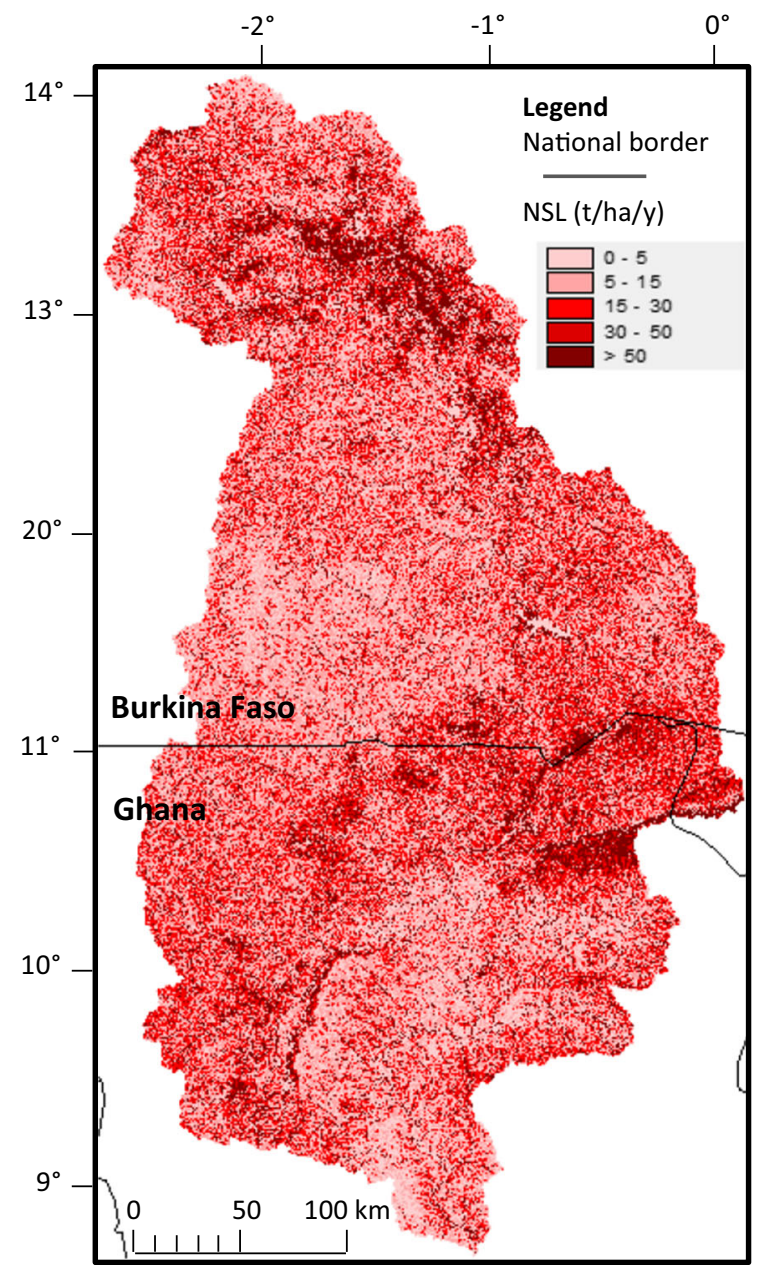

Fig. 3 Net soil loss $\left(\mathrm{t} \mathrm{ha} \mathrm{hr}^{-1}\right)$ of White Volta basin computed by SDR-adjusted RUSLE model. Note: pixel size used in the computation $=250 \mathrm{~m}$. (Color figure online) to delineating the patterns of erosion severity classes using the presented SDR-adjusted RUSLE model.

\section{Soil loss estimate and its spatial pattern in the Nile basin}

Due to major differences in landscape attributes as well as predicted erosion, we discuss the soil loss estimates of the Blue and White Nile Basins separately. In this paper, the White Nile basin refers to the region from Lake Victoria to Khartoum and Blue Nile basin from Ethiopian highlands to Khartoum (Fig. 1).

The average gross soil loss estimated for the Blue and White Nile Basins were about 140 and $45 \mathrm{t}$ $\mathrm{ha}^{-1} \mathrm{yr}^{-1}$, respectively. When adjusted for SDR, the NSL for the Blue Nile reached about $85 \mathrm{t} \mathrm{ha}^{-1} \mathrm{yr}^{-1}$ while that of the White Nile dropped to $6 \mathrm{tha}^{-1} \mathrm{yr}^{-1}$. As the RULSE does not consider gully and riverbank erosion, the soil loss estimates presented here, especially those of the Blue Nile may be underestimated. The significant reduction is soil loss when adjusted for SDR in the White Nile can be due to the flat landscape of the region especially major parts of the Sudan and South Sudan as well as the various lakes and swamps such as the Sudd, which the White Nile faces along its journey towards the north. Due to high intermediate deposition, the contribution of the White Nile to the Nile sediment discharge rate is $<5 \%$ (Ahmed and Ismail 2008).

The soil loss estimates made in this study are generally comparable with other similar studies though strict composition in some cases is not possible. Table 3 shows that the result of soil erosion

Table 2 Average net soil loss (NSL) for different sub-catchments in White Volta sub-basin estimated by field measurements and the respective results from this study

\begin{tabular}{|c|c|c|c|}
\hline \multicolumn{2}{|c|}{ Sub-catchments } & \multicolumn{2}{|l|}{ Average NSL(t ha ${ }^{-1} \mathrm{yr}^{-1}$ ) } \\
\hline Name & Catchment area (ha) & $\begin{array}{l}\text { Predicted by the RUSLE } \\
\text { model in this study }{ }^{1}\end{array}$ & $\begin{array}{l}\text { From } \\
\text { literature }\end{array}$ \\
\hline Doba & 70 & $22 \pm 3$ & $19^{2}$ \\
\hline Dua & 35 & $124 \pm 21$ & $103^{2}$ \\
\hline Zebila & 105 & $22 \pm 3$ & $27^{2}$ \\
\hline Bugri & 216 & $124 \pm 2$ & $8^{2}$ \\
\hline
\end{tabular}

1 Le et al. (2012) applied the same RUSLE model but used data inputs at a finer resolution, i.e., $100 \mathrm{~m}$ pixel size

2 Adwubi et al. (2009) 
Table 3 Average net soil loss (NSL) for different sub-catchments in the Nile sub-basin estimated by different studies

\begin{tabular}{|c|c|c|}
\hline Study site & Area $(\mathrm{km} 2)$ & $\begin{array}{l}\text { NSL/Sediment } \\
\text { yield }\left(\mathrm{t} \mathrm{ha}^{-1} \mathrm{yr}^{-1}\right)^{8}\end{array}$ \\
\hline Simiyu catchment, Tanzania ${ }^{1}$ & 10,312 & 984 \\
\hline El Diem, Upper Blue Nile outlet ${ }^{2}$ & NA & 4.91 \\
\hline Basin above El Diem catchment, Blue Nile ${ }^{3}$ & NA & 4.8 \\
\hline Upper Blue Nile and Tekeze basins ${ }^{4}$ & 275,000 & $2-4$ \\
\hline Ethiopian highlands ${ }^{5}$ & NA & $1-10$ \\
\hline Lake Tana basin, Ethiopia ${ }^{6}$ & 110 ha & $0-65$ \\
\hline Nyando catchment, Kenya ${ }^{7}$ & NA & 90 \\
\hline
\end{tabular}

1 Kimwaga et al. (2012), Jayakrishnan et al. (2005); ${ }^{2}$ Betrie et al. (2011); ${ }^{3}$ Hussein et al. (2005); ${ }^{4}$ McDougall et al. (1975); ${ }^{5}$ Walling 1984; ${ }^{6}$ Setegn et al. (2010); ${ }^{7}$ ICRAF/MARD (2000)

8 Net soil loss estimates in this study are $6 \mathrm{t} \mathrm{ha}^{-1} \mathrm{yr}^{-1}$ (White Nile, with an area of $186,000 \mathrm{~km}^{2}$ ) and $85 \mathrm{t} \mathrm{ha}^{-1} \mathrm{yr}^{-1}(\mathrm{Blue}$ Nile, with an area of $184,560 \mathrm{~km}^{2}$ ). The Figures in Table 3 should be considered indicative as comparing these values with NSL of While and/or Blue Nile can be challenging due to mainly differences in the size of areas involved

for the Blue Nile agreed with various studies conducted in the region. Though the models used are different and in some cases the areas of emphasis are not the same, the general agreement indicates that easy to use and accessible soil erosion models such as the RUSLE can be used to assess soil erosion risk and identify priority areas of intervention.

Figure 4 shows the spatial pattern of soil erosion in the Nile Basin. As described above, the map reveals the severity of erosion in the Ethiopian highlands compared to the other parts of the basin. Some areas of the White Nile sub-basin such as those in the highlands of Rwanda and Burundi also experienced relatively high soil loss though not comparable to those of the Blue Nile basin. Both areas experiencing high soil loss are characterized by high altitude and thus relatively high rainfall (over $1,500 \mathrm{~mm}$ per year), steep slope (over $25^{\circ}$ ) and high population density (Nyssen et al. 2005). This means that both the kinetic energy of water and gravitational forces are conducive for high runoff and soil movement. Some parts of the Blue Nile basin (its southwestern part), which have good surface cover (dense forest) and less areas under cultivation showed relatively low soil loss and sediment yield. It is important to note that few areas of steep slopes or river canyons have extreme soil loss rates which exaggerate the overall of soil loss. This is even more severe than the White Volta basin where extreme steep slope and deep river gorges are relatively rare.

Comparatively the Blue Nile, which contributes nearly $90 \%$ of the waters to the Nile River, experiences very high erosion risk than the White Nile and contributes the most flooding as well as sedimentation danger to downstream locations. This is one reason why observers at Khartoum where the two rivers meet witness the difference in the color of the waters in the rivers caused by differences in silt. The high level of soil loss in the Blue Nile is estimated to cost about 1.5 billion tons of topsoil in Ethiopia that could have added about 1.5 million ton of grain to the country (Taddese 2001). Such high level of erosion has also severe impact off-site. For example, the Sinnar dam in the Sudan has lost $65 \%$ of its original storage after 62 years operation (Shahin 1993) and other dams lost similar proportions since construction (Ahmed and Ismail 2008). In addition, sedimentation of irrigation canals in the Sudan costs the country millions of dollars per year for cleaning and dredging purposes. This highlights the need for joint investment between the upstream and downstream countries to sustainably manage the basin and tackle both on- and off-site impacts (BCEOM 1999; World Bank 2006).

\section{Data- and parameterization-induced uncertainties of the RUSLE results}

Despite the fact that we chose the RUSLE model that can be applied with easily available data compared to process-based models, its application at continental and regional scales can still be challenging. For instance, some of the inputs used in this study are derived based on suggestions and/or experimental studies within the region. This may have an implication on the soil loss estimates: it would be wise not to 


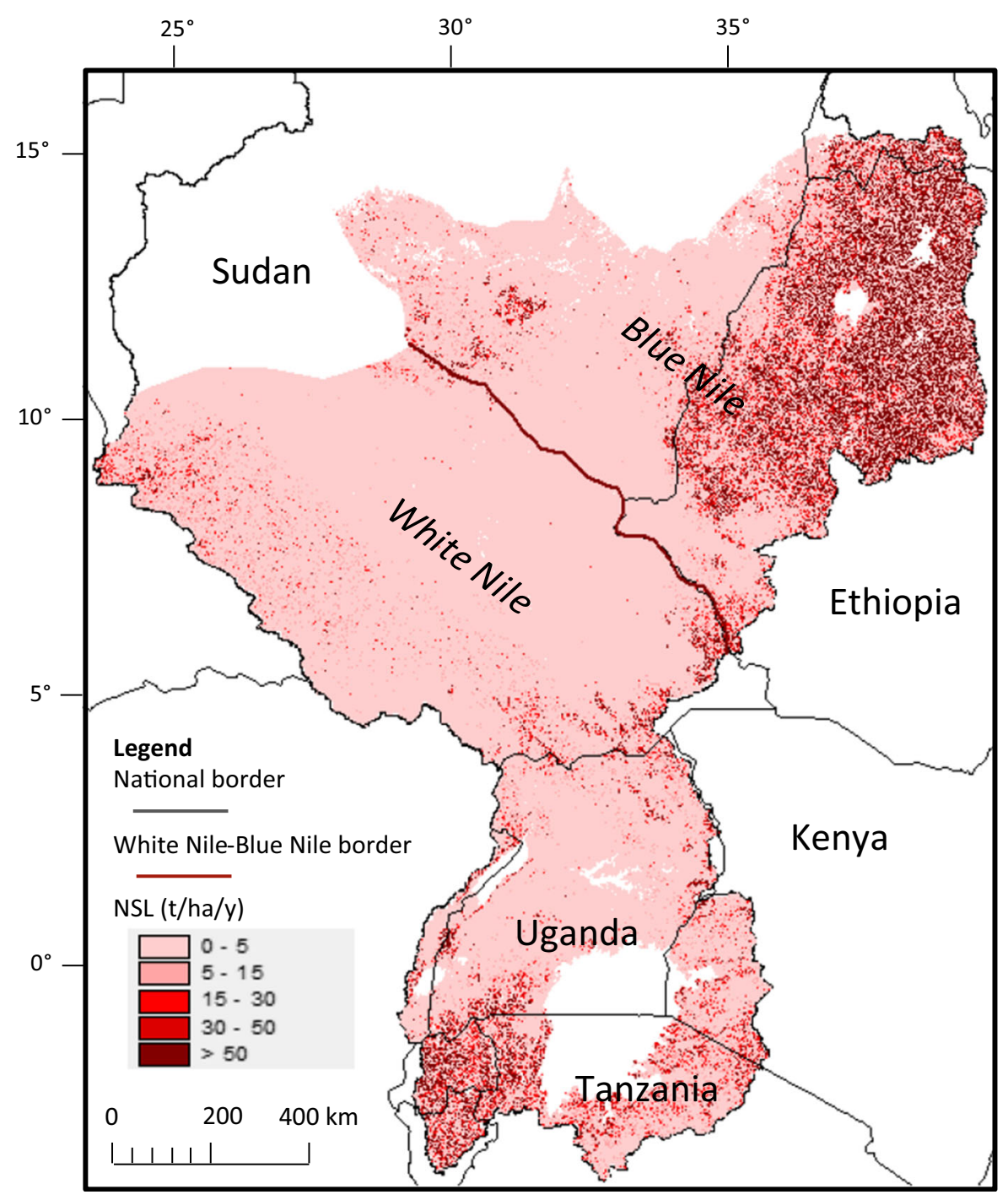

Fig. 4 Net soil loss $\left(\mathrm{t} \mathrm{ha}^{-1} \mathrm{yr}^{-1}\right)$ of the upper Nile basin computed by SDR-adjusted RUSLE model. Note: pixel size used in the computation $=250 \mathrm{~m}$. (Color figure online)

entirely consider the soil loss estimates as exact quantification of the process within each pixel. Rather, the results should be gauged (aggregated) as the best estimates available considering the available data. It is also wise to focus on spatial variability (differences across different areas) rather than the magnitude of soil loss. With this background, we discuss some of the issues that require attention when utilizing the results of such modelling exercises and mention some particular cases below. Such information is useful for those who wish to use the results of the study and/ or model inputs.
- Uncertainty related to rainfall erosivity: Rainfall erosivity is generally derived from rainfall intensity data. However, rainfall intensity is not available especially for basin and regional scale applications. As a result, mean annual rainfall has been used to derive the $R$-factor in different studies. Despite the fact that rainfall amount calibrated for rainfall intensity for respective regions is used, there can still be some degree of sensitivity when modelling soil erosion. In addition, it is important to note the sources of the input data (rainfall) when comparing model results. For 
instance, rainfall data from available rainfall recording stations are used for the White Volta for CRU-based rainfall data is used for the Nile basin.

- Uncertainty related to soil erodibility: Soil erodibility is one of the most difficult 'erosion factors' especially when applied at larger geographical extent. This is because it requires information on different parameters such as soil structure, permeability, texture and organic matter. In this study, erodibility is estimated based on key soil properties such as type, texture and organic matter, which are derived from published sources. In addition, the 'translations' between soil types-erodibility will have its own uncertainty. These could further introduce uncertainty in the quantitative values of soil loss per unit area. Like the case of rainfall, it is also essential to understand the sources of the soil erosion parameters used in the modelling exercise.

- Sensitivity related to surface cover factor: Land use/cover is one of the key components of soil erosion models. In the USLE and its derivatives, detailed land use/cover parameters (classes) are used to derive the $C$-factor. Generating accurate and detailed land use/cover factor is a challenge and its complexity increases when the size of the study area increases. As a result of such challenges, different studies tried to calibrate easily available data such as normalized difference vegetation index to derive the $C$-factor. In such instances, it is likely that the modelled soil erosion values will have uncertainty associated to them and it is essential to be cautious when using the quantitative soil loss estimates.

- Uncertainty related to the land management factor: Land management and conservation practices are introduced into soil erosion models to assess the impacts of different interventions on soil loss and sediment yield. Such interventions can be physical (e.g., stone bunds and trenches), or biological (e.g., afforestation and ex-closures). Mapping the extent and condition of such interventions at adequate spatial resolution is a challenge, especially when the geographical extent of the study area is large. In this study, $P$-factor value of 1 was used with the assumption that conservation practices at basin or regional level are insignificant and thus will have minimum impact in reducing erosion. This can contribute to increased soil loss estimate compared to plot-level detailed studies.

Considering the above points, it is generally important to take pre-caution when interpreting and using soil erosion model results, especially when applied at larger geographical areas and when adopting models developed and calibrated in different environmental conditions. Instead of using the soil loss estimates as exact quantification of the process within each pixel, it will be wise to use them as close approximations. It is also generally recommended that soil erosion modelling results be used to map spatial variability and identify areas with different soil erosion risk levels rathter than quantify soil loss rates, especially at large geographical areas.

Variation of soil erosion risk within SECEs and uncertainties of SECE-based extrapolation approach

The mean NSL values for the SECE units and their uncertainty (i.e., \pm confidence interval at $95 \%$ ) in the White Volta basin are shown in Table 1. Of the 16 SECE units (with the total area per unit $>10 \mathrm{~km}^{2}$ ) found in the basin, 9 units have uncertainty ranges equal to or less than $50 \%$ of their NSL mean values (see $\% \mathrm{CI}_{0.05}$ in Table 4). The other 4 SECE units have confidence intervals between 50 and $100 \%$ of the NSL mean values, which are less certain, compared to the 9 SECEs. The high uncertainty of the NSL mean values $(>100 \%)$ of the other remaining 3 SECE units suggests that the defined classes are too broad for biophysical heterogeneities of the land where these units occur. More detailed stratifications of these units into sub-SECEs and using them for extrapolation of RUSLE results would reduce uncertainty.

The estimation of NSL for each SECE unit in the upper Nile basin (95 units with the total area per unit $>10 \mathrm{~km}^{2}$ ) and related uncertainty are shown in Table S2 (Supplementary Information). There are 30 SECE units having confidence intervals $<50 \%$ of the unit's NSL mean. The other 40 SECEs have uncertainty range between $50-100 \%$ of the NSL means. The remaining 25 SECEs units have uncertainty more than $100 \%$ (see Table S2). Generally, uncertainty level seems to be higher in the Nile basin compared to the White Volta, which can be attributed to the complexity of the terrain and land use/cover types in the former. 
Table 4 Estimated net soil losses for SECEs found in White Volta basin and related uncertainties

\begin{tabular}{|c|c|c|c|c|c|}
\hline SECE unit ${ }^{1,2}$ & Area $\left(\mathrm{km}^{2}\right)$ & $\begin{array}{l}\text { Mean net soil loss } \\
\left(\mathrm{t} \mathrm{ha}^{-1} \mathrm{yr}^{-1}\right)(\bar{X})\end{array}$ & $\mathrm{SD}\left(\mathrm{t} \mathrm{ha}^{-1} \mathrm{yr}^{-1}\right)$ & $\begin{array}{l}\text { Confidence interval } \\
(p<0.05) \text { of mean } \\
\text { value }\left(\mathrm{CI}_{0.05}\right)\end{array}$ & $\begin{array}{l}\% \mathrm{CI}_{0.05} \\
\text { (compared to } \bar{X} \text { ) }\end{array}$ \\
\hline 3135 & 132 & 31 & 48 & 8 & 26 \\
\hline 2125 & 234 & 30 & 61 & 8 & 26 \\
\hline 3133 & 109 & 22 & 31 & 6 & 27 \\
\hline 3121 & 162 & 34 & 70 & 11 & 32 \\
\hline 2136 & 25 & 18 & 15 & 6 & 34 \\
\hline 2135 & 182 & 41 & 106 & 16 & 38 \\
\hline 3132 & 34 & 19 & 22 & 8 & 41 \\
\hline 3123 & 293 & 49 & 180 & 21 & 42 \\
\hline 3122 & 122 & 35 & 101 & 18 & 51 \\
\hline 3115 & 29 & 26 & 40 & 16 & 61 \\
\hline 2115 & 93 & 91 & 316 & 65 & 72 \\
\hline 2134 & 12 & 13 & 18 & 12 & 89 \\
\hline 3125 & 230 & 58 & 414 & 54 & 93 \\
\hline 2126 & 13 & 40 & 68 & 43 & 107 \\
\hline 2132 & 13 & 41 & 78 & 49 & 119 \\
\hline 3113 & 15 & 106 & 284 & 163 & 154 \\
\hline
\end{tabular}

1 See Table 1 for the meaning of the 4-digit code of CECE

${ }^{2}$ SECE with the area $<10 \mathrm{~km}^{2}$ (i.e. $<10$ pixels) are not showed

In conditions where uncertainty levels are $<50 \%$, the NSL computed for the respective SECE units can be applied in the same categories elsewhere in SSA with a much higher certainty compared to some very coarse erosion estimations made either at sub-basin scale-e.g., 1-10 $\mathrm{t} \mathrm{ha}^{-1} \mathrm{yr}^{-1}$ (uncertainty range = $550 \%$ of the mid-point) by Walling (1984), 0-65 t $\mathrm{ha}^{-1}$ (uncertainty range $=200 \%$ of the mid-point) by Setegn et al. (2010) (see Table 3); or global scalee.g., 23.7-64.9 $\mathrm{Pg}^{-1}$ soil lost from global crop land (uncertainty range $=93 \%$ of the mid-point) by Stallard (see the review of Quinton et al. 2010).

The result in this study demonstrates the possibility to employ similar approaches used in the generation of SECEs in circumstances where modelling soil loss at continental scale using soil erosion models is difficult. Estimation of the uncertainty levels can help evaluate where the estimated result gives enough confidence and where the uncertainty is high that requires finer data to improve the result. With detailed analyses at selected basins or landscapes, uncertainty of the estimations based on SECEs and their usefulness to highlight area of similar degradation level can be improved.

\section{Conclusion}

Understanding land degradation process requires acquisition of detailed information on spatially distributed phenomena as well as huge computation power and time. There is therefore a tendency to focus on either small geographical scale but with detailed process understanding or cover wide geographical region but using coarse resolution data. In this study we employ different approaches to derive land degradation risk at sub-continental and regional scales. For the sub-continental (SSA) scale, coarse resolution but physically meaningful data were used to derive homogeneous environmental units called SECEs. These 'envelopes' are derived based on key biophysical and human constraints and are expected to have similar impacts and thus produce similar landscape features. In order to provide more quantitative physical meaning, the RUSLE was used to estimate soil erosion risk and its spatial patterns at regional or watershed levels (White Volta and Nile basins). The estimated NSL were evaluated by comparing with other estimates made within the respective regions. 
Results show that the Nile basin experienced average NSL of about $75 \mathrm{t} \mathrm{ha}^{-1} \mathrm{yr}^{-1}$ ) while the White Volta basis showed average NSL of $28 \mathrm{t}$ $\mathrm{ha}^{-1} \mathrm{yr}^{-1}$ ). In both cases, extreme soil loss in few areas has contributed the overall average erosion to increase. Within the Nile basin, the Blue Nile of the Ethiopian highlands experiences high soil loss and sediment yield compared to the White Nile. There is also spatial variability in soil loss in the White Volta basin where high NSLs are experienced in the Upper East Region of Ghana and around the Ghana-Burkina Faso border.

The pixel-based NSL estimates were aggregated for each SECE to evaluate the certainty/uncertainty of the SECE-aggregated NSL if extrapolated to similar SECEs in the region. Generally, the majority of the SECE classes compared well with NSL values with lower uncertainty levels while in some cases uncertainty level was higher. In cases where uncertainties are low, there is a possibility to use the 'easy to derive' SECEs to assess soil degradation risk. The work in this study thus can provide guidance on where the estimated NSL can be extrapolated with respect to the different SECEs, and where finer SECE sub-units should be defined to further collapse the spatial variability of drivers of soil erosion. The results of this study can also serve as a benchmark against which future trend and change can be compared.

\section{References}

Abe SS, Wakatsuki T (2011) Sawah ecotechnology—a trigger for a rice green revolution in sub-Saharan Africa: basic concept and policy implications. Outlook Agric 40(3):221-227

Adwubi A, Amegashie BK, Agyare WA, Tamene L, Odai SN, Quansah C, Vlek PLG (2009) Assessing sediment inputs to small reservoirs in Upper East Region, Ghana. Lakes Reserv Res Manag 14:279-287

Ahmed AA, Ismail UHA (2008) Sediment in the Nile River System. UNESCO International Hydrological Programme International Sediment Initiative, UNESCO Chair in Water Resources, Khartoum

Balk D, Yetman G (2004) Gridded population of the worldversion 3 documentation. Center for International Earth Science Information Network (CIESIN), Columbia University, New York

Batjes NH (2001) Options for increasing carbon sequestration in West African soils: an explanatory study with special focus on Senegal. Land Degrad Dev 12:131-142

BCEOM (1999) Abay River Basin integrated master plan, main report. Ministry of Water Resources, Addis Ababa, pp. 71-83
Betrie GD, Mohamed YA, van Griensven A, Srinivasan R (2011) Sediment management modelling in the Blue Nile basin using SWAT model. Hydrol Earth Syst Sci 15:807-818

Bicheron P, Defourny P, Brockmann C, Schouten L, Vancutsem C, Huc M, Bontemps S, Leroy M, Achard F, Herold M, Ranera F, Arino O (2008) GLOBCOVER: products description and validation report. ESA Globcover Project, led by MEDIAS-France/POSTEL

Bishop J, Allen J (1989) On-site costs of soil erosion in Mali. Environment department working paper no. 21, World Bank, Washington

Bull LJ, Kirkby MJ, Shannon J, Dunsford HD (2003) Predicting hydrologically similar surfaces (HYSS) in semi-arid environments. Adv Monit Model 1:1-26

Chowdary VM, Chakraborthy D, Jeyaram A, Murthy YVNK, Sharma JR, Dadhwal VK (2013) Multi-criteria decision making approach for watershed prioritization using analytic hierarchy process technique and GIS. Water Resour Manag 27:3555-3571

Curran-Everett D, Benos DJ (2004) Guidelines for reporting statistics in journals published by the American Physiological Society. Adv Physiol Educ 28:85-87

Desmet PJJ, Govers G (1996) A GIS procedure for automatically calculating the USLE LS factor on topographically complex landscape units. J Soil Water Conser 51:427-443

Droogers P, Kaufman JH, Dijkshoorn JA, Immerzeel W, Huting JRM (2006) Green water credits: basin identification. Green Water Report 1. ISRIC report 2006/4. World Soil Information (ISRIC), Wageningen

Ejeta G (2010) African green revolution needn't be a mirage. Science 327(5967):831-832

Eswaran H, Lal R, Reich PF (2001) Land degradation: an overview, In: Proceedings of the 2nd International Conference on Land Degradation and Desertification, pp. 1-5, Oxford Press, Khon Kaen

FAO (1995) Land and environmental degradation and desertification in Africa. FAO Corporate Document Repository, Rome

Fargas D, Martínez-Casasnovas JA, Poch RM (1997) Identification of critical sediment source areas at regional level. Phys Chem Earth 22:355-359

Fischer G, van Velthuizen HT, Shah M, Nachtergaele FO (2002) Global agroecological assessment for agriculture in the 21st century - methodology and results. International Institute for Applied Systems Analysis (IIASA) and food and agriculture organization of the United Nations (FAO), Laxenburg, Austria

Fischer G, Nachtergaele F, Prieler S, van Velthuizen HT, Verelst L, Wiberg D (2008) Global agro-ecological zones assessment for agriculture (GAEZ 2008). IIASA, Laxenburg

Flügel WA (1996) Hydrological Response Units (HRUs) as modelling entities for hydrological river basin simulation and their methodological potential for modelling complex environment process systems. Results from the Sieg Catchment. Erde 127:43-62

Flügel WA (1997) Combining GIS with regional hydrological modelling using hydrological response units (HRUs): an application from Germany. Math Comput Simul 43:297-304

Flügel WA, Märker M, Moretti S, Rodolfi G, Sidrochuk A (2003) Integrating geographical information systems, remote sensing, ground truthing and modelling approaches for regional erosion classification of semi-arid catchments in South Africa. Hydrol Process 17:929-942 
Folly A (1997) Land use planning to minimize soil erosion-a case study from the upper east region in Ghana. Institute of Geography. University of Copenhagen, Copenhagen

Garg V, Jothiprakash V (2012) Sediment yield assessment of a large basin using PSIAC approach in GIS environment. Water Resour Manag 26:799-840

Hazell P, Poulton C, Wiggins S, Dorward A (2010) The future of small farms: trajectories and policy priorities. World Dev 38:1349-1361

Henao J, Baanante C (2006) Agricultural production and soil nutrient mining in Africa implications for resource conservation and policy development. IFDC Technical Bulletin www.ifdc.org

Hochschild V, Märker M, Rodolfi G, Staudenrausch H (2003) Delineation of erosion classes in semi-arid southern African grasslands using vegetation indices from optical remote sensing data. Hydrol Process 17(5):917-928

Hurni H (1985) Erosion: productivity-conservation systems in Ethiopia. In: Proceedings 4th international conference on soil conservation, Maracay, pp. 654-674

Hussein AS, Bashar KE, Fattah SA, Siyam AM (2005) Reservoir sedimentation. Nile Basin Capacity Building Network (NBCBN), Khartoum

ICRAF/MARD (2000) "Improved land management in the Lake Victoria basin: linking land and lake, research land extension, catchment and lake basin", Final Technical Report, Start-up Phase

ISRIC-World Soil Information (2013) Soil property maps of Africa at $1 \mathrm{~km}$. Available for download at www.isric.org

Jayakrishnan R, Srinivasan R, Santhi C, Arnold JG (2005) Advances in the application of the SWAT model for water resources management. Hydrol Proc 19:683-692

Jones P, Harris I (2008) CRU time-series (TS) high resolution gridded datasets. http://badc.nerc.ac.uk/view/badc.nerc.ac. uk_ATOM_dataent_1256223773328276 (Accessed on 01 May 2013). NCAS British Atmospheric Data Centre Climate Research Unit (CRU), University of East Anglia

Kaboré D, Reij C (2004) The emergence and spreading of an improved traditional soil and water conservation practice in Burkina Faso. EPTD Discussion Paper No. 114. International Food Policy Research Institute, Washington

Kimwaga RJ, Mashauri DA, Bukirwa F, Banadda N, Wali UG, Nhapi I (2012) Development of best management practices for controlling the non-point sources of pollution around Lake Victoria using SWAT model: a case of Simiyu catchment, Tanzania. Open Environ Eng J 5:77-83

Lal R (1995) Erosion-crop productivity relationships for soils of Africa. Soil Sci Soc Am J 59(3):661-667

Lawal O, Thomas G, Babatunde N (2007) Estimation of potential soil losses on a regional scale: a case of AbomeyBohicon region. Benin Republic Agric J 2:1-8

Le Roux JJ, Morgenthal TL, Malherbe J, Pretorius DJ, Sumner PD (2008) Water erosion prediction at a national scale for South Africa. Water SA 34:305-314

Le QB, Tamene L, Vlek PLG (2012) Multi-pronged assessment of land degradation in West Africa to assess the importance of atmospheric fertilization in masking the processes involved. Global Planet Change 92-93:71-81

Marker M, Moretti S, Rodolf G (2001) Assessment of water erosion processes and dynamics in semiarid regions of southern Africa (Kwazulu/Natal RSA; Swaziland) using the Erosion Response Unit concept (ERU). Geografia, Fisica e dinamica Quaternaria 24:71-83

Mati BM, Veihe A (2001) Application of the USLE in a savannah environment: comparative experiences from East and West Africa. Singap J Trop Geogr 22:138-155

McDougall I, Morton W, William M (1975) Ages and rates of denudation of trap series basalts at the Blue Nile Gorge, Ethiopia. Nature 254:207-209

Moore ID, Burch GJ (1986) Modelling erosion and deposition: topographic effects. Trans Am Soc Agric Eng 29:1624-1630

Moore ID, Grayson RB, Ladson AR (1991) Digital terrain modelling: a review of hydrological, geomorphological and biological applications. Hydrol Process 5:3-30

Nile Basin Initiative (2012) State of the River Nile Basin 2012 Nile Basin Initiative (NBI), Entebbe

Nyssen J, Haregeweyn N, Descheemaeker K, Gebremichael D, Vancampenhout K, Poesen J, Haile M, Moeyersons J, Buytaert W, Naudts J, Deckers J, Govers G (2005) Modelling the effect of soil and water conservation practices in Tigray, Ethiopia. Agric Ecosyst Environ 114:407-411

Obalum SE, Buri MM, Nwite JC, Watanabe Y, Hermansah, Igwe CA, Wakatsuki T (2012) Soil degradation-induced decline in productivity of sub-Saharan African soils: the prospects of looking downwards the lowlands with the sawah ecotechnology. Appl Environ Soil Sci. doi:10.1155/2012/673926

Oldeman LR, Hakkeling RTA, Sombroek WG (1991) World map of the status of human-induced soil degradation: an explanatory note. International Centre and United Nations Environment Programme. Wageningen, Nairobi

Quinton JN, Govers G, van Oost K, Bardgett RD (2010) The impact of agricultural soil erosion on biogeochemical cycling. GeoNature 3:311-314

Reij C, Tappan G, Belemvire A (2005) Changing land management practices and vegetation on the central plateau of Burkina Faso (1968-2002). J Arid Environ 63:642-659

Renard KG, Freimund JR (1994) Using monthly precipitation data to estimate the R-factor in the revised USLE. J Hydrol 157:287-306

Renard KG, Foster GR, Weesies GA, McCool DK, Yoder DC (1997) Predicting soil erosion by water: a guide to conservation planning with the Revised universal soil loss equation (RUSLE). USDA agricultural handbook 703

Roose EJ (1977) Erosion et Ruissellement en Afrique de l'ouest-vingt annees de mesures en petites parcelles experimentales. Travaux et Documents de I'ORSTOM No. 78. ORSTOM, Paris

Roy RN, Misra RV, Lesschen JP, Smaling EM (2003) Assessment of soil nutrient balance: approaches and methodologies. FAO Fertilizer and Plant Nutrient Bulletin 14. FAO, Rome, Italy

Sanchez PA, Shepherd KD, Soule MJ, Place FM, Buresh RJ, Izac AN, Mokwunye AU, Kwesiga FR, Ndiritu CG, Woomer PL (1997) Soil fertility replenishment in Africa: an investment in natural resource capital. In: Replenishing soil fertility in Africa, soil science society of America special publication \#51, Soil science society of America, Madison

Scherr SJ, (1999) Soil degradation: a threat to developingcountry food security by 2020 ? IFPRI food, agriculture and the environment discussion paper 27

Setegn S, Dargahi B, Srinivasan R, Melesse A (2010) Modeling of sediment yield from Anjeni-Gauged Watershed, Ethiopia using SWAT model. J Am Water Resour 46:514-526 
Shahin M (1993) An overview of reservoir sedimentation in some African river basins, In: Proceedings of sediment problems: strategies for monitoring, prediction and control, yokohama, July 1993, LAHS Publ 217, pp. 93-100

Stocking MA (1987) Measuring land degradation. In: Blackie P, Brookfield $\mathrm{H}$ (eds) Land degradation and society. Methuen, London, pp 49-63

Stocking M, Benites JR (1996) Erosion-Induced loss in soil productivity: second workshop-Preparatory papers and country report analyses. Report of the workshop, Chapecó, Santa Catarina, Brazil. UN food and agriculture organization, land and water development division

Symeonakis E, Drake N (2004) Monitoring desertification and land degradation over sub-Saharan Africa. Int J Remote Sens 25:573-592

Symeonakis E, Drake N (2010) 10-Daily soil erosion modelling over sub-Saharan Africa. Environ Monit Assess 161:369-387

Taddese G (2001) Land degradation: a challenge to Ethiopia. Environ Manage 27:815-824

Tamene L, Le QB, Vlek PLG (2014) A landscape planning and management tool for land and water resources management: an example application in Northern Ethiopia. Water Resour Manage 28:407-424

van der Knijff JM, Jones RJA, Montanarella L (1999) Soil erosion risk assessment in Italy. European Soil Bureau, JRC, Italy. http://eusoils.jrc.ec.europa.eu/ESDB_Archive/ eusoils_docs/other/er_it_new.pdf

van der Knijff JM, Jones RJA, Montanarella L (2000) Soil Erosion assessment in Europe. European soil bureau, Joint research center of the European commission, pp. 34

Van Leeuwen WJD, Sammons G (2003) Seasonal land degradation risk assessment for Arizona. The 30th International symposium on remote sensing of environment, Honolulu

Van Leeuwen WJD, Sammons G (2005) Vegetation dynamics and erosion modeling using remotely sensed data (MODIS) and GIS. Tenth Biennial USDA "forest service remote sensing applications" conference. U.S. Department of Agriculture, forest service remote sensing applications Center, Salt Lake City
Van Rompaey A, Bazzoffi P, Jones RJA, Montanarella L (2005) Modeling sediment yields in Italian catchments. Geomorphology 65:157-169

Veldkamp WJ (2002) Experiences on land degradation and its mitigation and best management practices under semi-arid conditions in sub-Saharan Africa. FAO Working Paper Rome

Vlek PLG, Le QB, Tamene L (2010) Assessment of land degradation, its possible causes and threat to food security in Sub-Saharan Africa. In: Lal R, Stewart BA (eds) Advances in soil science-food security and soil quality. CRC Press, Boca, pp 57-86

Vrieling A (2006) Satellite remote sensing for water erosion assessment: a review. Catena 65:2-18

Walling DE (1984) A challenge of african hydrology and water resources. International Association of Hydrological Sciences. IAHS Publication 144: 37693-587

Warren A, Batterbury S, Osbahr H (2001) Soil erosion in the West African Sahel: a review and an application of a"local political ecology" approach in South West Niger. Glob Environ Change 11(1):79-95

Wischmeier WH, Smith DD (1978) Predicting rainfall erosion losses: a guide to conservation planning. Agriculture handbook No. 537. U.S. Department of Agriculture, Washington

Wischmeier WH, Johnson CB, Cross BV (1971) A soil erodibility nomograph for farmland and construction sites. J Soil Water Conserv 26:189-193

World Bank (2006) Africa development indicators 2006. The International Bank for Reconstruction and Development/ World Bank, Washington

Xin Z, Yu X, Li Q, Lu XX (2010) Spatiotemporal variation in rainfall erosivity on the Chinese loess plateau during the period 1956-2008. Reg Environ Change 11(1):149-159

Yang D, Kanae S, Oki T, Koike T, Musiake K (2003) Global potential soil erosion with reference to land use and climate change. Hydrol Processes 17:2913-2928 